\title{
原著 XII
}

\section{成分栄養法による大腸手術前処置に伴う腸内細菌叢の 変動についての実験的, 臨床的検討}

\author{
一とくに抗菌剤併用の有効性について一
}

\author{
東邦大学外科学第 3 講座 \\ 炭山嘉伸長尾二郎中 村集
}

大腸癌手術症例の術後合併症としての創部感染や縫合不全の発生の因子として，腸内容の存在があげられ る.これに対する術前の処置 (colon preparation) の重要性について，実験的臨床的検討を行った。 実験的 検討については，Wistar 系ラットを用い，成分栄養法 (ED) を行ったのち抗菌剂として Kanamycin (KM), Metronidezole (MTN), KM+MTN をそれぞれ 4 日閒経口投与し, 腸内容についての好気性菌, 嫌気性菌 の変動を ED 単独群と比較検討した. さらにラットの横行結腸に狭窄を作成し, 同様の検討を行った. 臨床 的検討では，狭窄のあまり強度ではない，すなわち十分な機械的 preparation の期待できる大腸癌症例を対 象に, $\mathrm{ED}$ 単独群, $\mathrm{ED}+\mathrm{KM}$ 群, $\mathrm{ED}+\mathrm{MTN}$ 群, $\mathrm{ED}+\mathrm{KM}+\mathrm{MTN}$ 群について, 術中腸内容を採取し, 細菌学的検討を行った.

結果：(1)腸内細菌叢の変動からみて, ED 単独使用による細菌学的効果は狭窄（一）群においては若干認 められたが，狭窄 $(+)$ 群では無効であり，ED による機械的 preparation に加え抗菌剤の投与が必要と 思われた. (2)好気性菌, 嫌気性菌両方に対寸る抗菌作用から, antibacterial preparation としては Kanamycin と Metronidazole の併用が有効であることが実験的, 臨床的検討から確認された. 以上から, 宿便傾向 にある，大腸癌手術症例に対しては， ED による mechanical preparation に加え， KM+MTN による antibacterial preparation が術前処置として重要であると思われた.

索引用語 : 成分栄養法, 腸内細菌叢, 大腸癌術前処置.

\section{I. 緒 言}

大腸手術前処置（以下 colon preparation）は機械的 要素 (mechanical preparation) と細菌学的要素 (antibacterial preparation) に大別することができる. 大腸 外科においては, これら mechanical antibacterial の 両面にわたる配慮が，創感染・縫合不全などの術後合併 症の防止，しいては手術成績の向上につながると言える ところが，他の消化器外科手術と異なるところである。

われわれは，以前より成分栄養法（以下 ED）が，ほ とんど残渣を残すことなく十分なカロリー投与が可能で あるという特性に注目し，大腸外科における mechanical colon preparation に使用し, その有効性を実験・ 臨床両面で認め報告してきた1,2).

一方の antibarterial preparation については，抗菌剤 の併用投与の是非, 効果などが問題点となっていたが, 教室の炭山 ${ }^{3)}$, 横山ら ${ }^{4)}$ は大腸癌に伴う腸管の通過障害
を想定し，ラットの結腸に狭窄モデルを作成するという 新しい見地から実験的検討を行い，ED が mechanical preparation としてだけでなく, Kanamycin, Metronidazole との併用により antibacterial preparation として も有効な方法であることを報告している.

本稿では, ラットの antibacterial preparation に関 する実験の概要を述べるとともに, 臨床例として大腸癌 手術症例に対する ED と Kanamycin, Metronidazole 併用時の腸内細菌叢の変動についての検討を加え, われ われの大腸手術前処置についての考えを述べる.

\section{II. ラットによる実験的検討}

1. 方 法

実験には体重 $220 \mathrm{~g}$ 前後の WISTAR 系ラットを使 用し, 表 1 のごとく, 固形飼料（クレア C-II）または, $\mathrm{ED}$ (エレンタール) を自由摂取させ，各群について， 抗菌剂非投与例 (以下抗菌剂 (一) 群), Kanamycin 50 


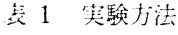

固形䬲料群
ED 群

落 2 分維選抧培地

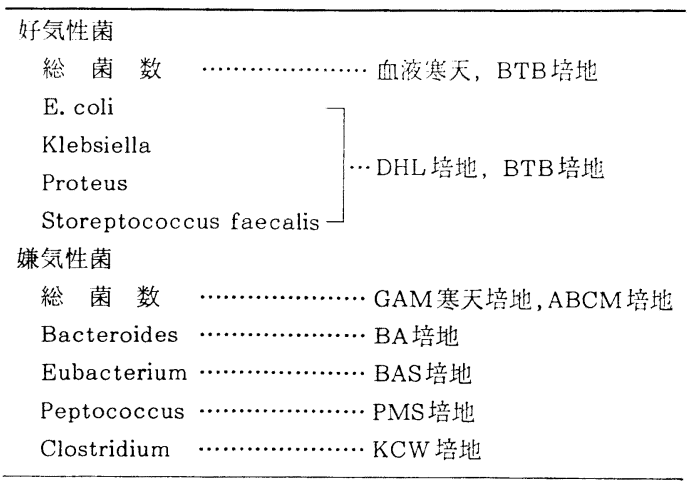

$\mathrm{mg} /$ 日経口投与例 (以下 $\mathrm{KM}$ 群), Metronidazole $10 \mathrm{mg} /$ 日経口投与例 (以下 MTN 群), Kanamycin $50 \mathrm{mg}$ /日, Metronidazole $10 \mathrm{mg} /$ 日併用投与例（以下 $\mathrm{KM}+\mathrm{MTN}$ 群）の 4 群に分け， 4 日間各抗菌剂投与後に屠殺開腹 し, 上行結腸内の便 $0.3 \mathrm{~g}$ を採取し, 後述する方法で細 菌の同定, 菌数の測定を行った。以上を狭窄 (一) 群と し, 次に炭山ら ${ }^{2,3)}$ の方法に従い, ラットの横行結腸に 内径 $4 \mathrm{~mm}$ のシリコーンチューブによる『狭窄』を作成 した狭窄（十）群においても，同様に 4 群に分け，狭窄 作成部口側の上行結腸内の便についての菌検索を行い， 各抗菌剤の効果としての生菌数の減少について, 固形飼 料群と $\mathrm{ED}$ 群の比較検討を行い，また狭窄作成時の変 化を検討した.

細菌の同定および菌数計算の方法は, 採取した腸内容 $0.3 \mathrm{~g}$ を GAMboth $5.7 \mathrm{~g}$ に入れ，10倍希釈系列を 5 系 列作成し, 便 $1 \mathrm{~g}$ 中の生菌数として求めた. また検索菌 種としては, 臨床例における感染起因菌として頻度の高 いものを選択し5,6,7) 好気性菌として E. coli, Klebsiella, Proteus, Strept. faecalis の 4 種および好気性菌総数を, 嫌気性菌としては Bacteroides 属, Eubacterium 属, Peptococcus 属, Clostridium 属と嫌気性菌総数を選び, 表 2 のごとき分離選択培地を使用した。好気性菌は $37^{\circ} \mathrm{C}, 48$ 時閒好気培養, 嫌気性菌は Forma 社の anarobic incubator にて $37^{\circ} \mathrm{C}$, 48時間嫌気培養を行った. コ 口ニ一数より菌数を求め, 好気菌の同定にはグラム染 色，パイルチューブ No-2を用い，嫌気性菌については，

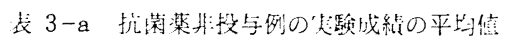

\begin{tabular}{|c|c|c|c|c|}
\hline & \multicolumn{2}{|c|}{ 狄窄 (一) 群 } & \multicolumn{2}{|c|}{ 狭窄 $(\div)$ 群 } \\
\hline & $\begin{array}{l}\text { 固 型 } \\
\text { 䬲料群 }\end{array}$ & ED游 & $\begin{array}{l}\text { 固 型 } \\
\text { 飼料群 }\end{array}$ & ED瞕 \\
\hline E. coli & $4.0 \times 10^{9}$ & $2.3 \times 10^{6}$ & $5.5: 10^{8}$ & $1.5 \cdot 10^{8}$ \\
\hline Klebsiella & $2.0 \div 10^{8}$ & $6.4 \cdot 10^{5}$ & $5.7 \times 10^{7}$ & $2.4 \times 10^{6}$ \\
\hline Proteus & $3.0 \times 10^{8}$ & $4.2 \div 10^{5}$ & $2.9 \times 10^{9}$ & $10>$ \\
\hline D-streptococcus & $2.9 \times 10^{6}$ & $3.8 \times 10^{6}$ & $1.3 \cdot 10^{8}$ & $2.5 \cdot 10^{8}$ \\
\hline 好気性菌総菌数 & $1.2 \times 10^{10}$ & $3.2 \times 10^{9}$ & $5.0 \times 10^{9}$ & $1.1 \cdot 10^{1 \mathrm{C}}$ \\
\hline Bacteroides & $2.9 \times 10^{9}$ & $5.6 \times 10^{6}$ & $4.5: 10^{9}$ & $6.3 \cdot 10^{9}$ \\
\hline Eubacterium & $2.3 \times 10^{4}$ & $2.0 \times 10^{2}$ & $1.2 \times 10^{6}$ & $4.0 \cdot 10^{?}$ \\
\hline Peptococcus & $6.7 \times 10^{2}$ & $1.2 \times 10^{2}$ & $10>$ & $4.0 \div 10^{7}$ \\
\hline Clostridium & $6.0 \times 10^{7}$ & $2.3 \times 10^{4}$ & $4.6 \times 10^{7}$ & $2.4 \cdot 10^{6}$ \\
\hline 嫌気性菌総菌数 & $6.9 \times 10^{9}$ & $6.8 \times 10^{8}$ & $1.3 \times 10^{10}$ & $7.2 \times 10^{9}$ \\
\hline
\end{tabular}

表 3-b カナマイシン投与例の実験成緹の平均值

\begin{tabular}{l|c|c|c|c}
\hline \multirow{2}{*}{} & \multicolumn{2}{|c|}{ 狭窄 $(-)$ 群 } & \multicolumn{2}{|c}{ 狭窄 $(+)$ 群 } \\
\cline { 2 - 5 } & $\begin{array}{c}\text { 固 型 } \\
\text { 飼料群 }\end{array}$ & ED 群 & $\begin{array}{c}\text { 固 型 } \\
\text { 飼料群 }\end{array}$ & ED群 \\
\hline E. coli & $5.6 \times 10^{4}$ & $10>$ & $7.2 \times 10^{4}$ & $1.2 \times 10^{5}$ \\
Klebsiella & $6.0 \times 10^{3}$ & $10>$ & $10>$ & $10>$ \\
Proteus & $1.0 \times 10^{4}$ & $10>$ & $1.6 \times 10^{6}$ & $10>$ \\
D-streptococcus & $4.4 \times 10^{5}$ & $2.6 \times 10^{5}$ & $7.0 \times 10^{7}$ & $2.6 \times 10^{8}$ \\
好気性菌総菌数 & $1.2 \times 10^{8}$ & $3.3 \times 10^{6}$ & $2.3 \times 10^{9}$ & $1.3 \times 10^{9}$ \\
\hline Bacteroides & $5.2 \times 10^{8}$ & $4.6 \times 10^{9}$ & $1.0 \times 10^{9}$ & $8.3 \times 10^{8}$ \\
Eubacterium & $2 \times 10^{4}$ & $4.7 \times 10^{2}$ & $10>$ & $10>$ \\
Peptococcus & $10>$ & $10>$ & $10>$ & $10>$ \\
Clostridium & $10>$ & $5.2 \times 10^{3}$ & $1.2 \times 10^{7}$ & $4.0 \times 10^{7}$ \\
嫌気性菌総菌数 & $2.6 \times 10^{9}$ & $7.4 \times 10^{9}$ & $1.3 \times 10^{9}$ & $8.9 \times 10^{8}$ \\
\hline
\end{tabular}

㜪 3-c メトロニダゾール投与例の尖験战絈の平均值

\begin{tabular}{|c|c|c|c|c|}
\hline & \multicolumn{2}{|c|}{ 狭 窄 $($ (一) 群 } & \multicolumn{2}{|c|}{ 㹨窄 $(+)$ 群 } \\
\hline & $\begin{array}{l}\text { 固 型 } \\
\text { 飼料群 }\end{array}$ & $\mathrm{ED}$ 群 & $\begin{array}{l}\text { 固 型 } \\
\text { 飼料群 }\end{array}$ & ED群 \\
\hline E. coli & $1.9 \times 10^{7}$ & $7.7 \times 10^{8}$ & $1.1 \times 10^{9}$ & $8.4 \times 10^{7}$ \\
\hline Klebsiella & $2.8 \times 10^{6}$ & $4.0 \times 10^{7}$ & $1.5 \times 10^{7}$ & $10>$ \\
\hline Proteus & $10>$ & $2.0 \times 10^{4}$ & $1.0 \times 10^{7}$ & $4.8 \times 10^{2}$ \\
\hline D-streptococcus & $3.9 \times 10^{7}$ & $2.6 \times 10^{7}$ & $2.4 \times 10^{8}$ & $8.8 \times 10^{7}$ \\
\hline 好気性菌総菌数 & $5.8 \times 10^{8}$ & $2.8 \times 10^{9}$ & $2.4 \times 10^{9}$ & $3.7 \times 10^{8}$ \\
\hline Bacteroides & $2.7 \times 10^{6}$ & $2.2 \times 10^{5}$ & $2.1 \times 10^{7}$ & $1.2 \times 10^{7}$ \\
\hline Eubacterium & $10>$ & $10>$ & $10>$ & $10>$ \\
\hline Peptococcus & $10>$ & $10>$ & $10>$ & $10>$ \\
\hline Clostridium & $10>$ & $1.8 \times 10^{4}$ & $5.0 \times 10^{5}$ & $8.1 \times 10^{5}$ \\
\hline 嫌気性菌総菌数 & $4.1 \times 10^{8}$ & $4.5 \times 10^{7}$ & $3.9 \times 10^{7}$ & $1.1 \times 10^{8}$ \\
\hline
\end{tabular}

グラム染色，ガスクロマトグラフィー，ミニテック法に よる糖分解の検討を行った。

2. 結 果

各群におけるラット 5 匹の指標菌の検出菌数の平均值 を表 3 に示した。 
教 3-d カナマイシン・メトロニダゾール 侻湖投与例の実験成績の平均值

\begin{tabular}{|c|c|c|c|c|}
\hline & \multicolumn{2}{|c|}{ 㷋窄 (一) 群 } & \multicolumn{2}{|c|}{ 狭窄 $(+)$ 洋 } \\
\hline & 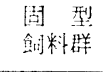 & ED群 & $\begin{array}{l}\text { 周 型 } \\
\text { 全问料群 }\end{array}$ & ED群 \\
\hline E. coli & $7.2 \cdot 10^{3}$ & $4 \cdot 10^{3}$ & $410^{7}$ & $4 \times 10^{5}$ \\
\hline Klebsiella & $4.1 \times 10^{2}$ & $10>$ & $1.5 \cdot 10^{7}$ & $10>$ \\
\hline Proteus & $1.2 \times 10^{3}$ & $10>$ & $10>$ & $10>$ \\
\hline D-streptococcus & $8.4 \times 10^{8}$ & $2.9 \cdot 10^{7}$ & $1.3 \times 10^{9}$ & $4.0 \times 10^{8}$ \\
\hline 好父、性藩総菌数 & $9.7 \cdot 10^{8}$ & $5.8 \times 10^{8}$ & $1.1 \times 10^{9}$ & $8.3 \times 10^{9}$ \\
\hline Bacteroides & $4.4 \cdot 10^{6}$ & $3.0 \times 10^{6}$ & $2.1 \times 10^{8}$ & $3.2 \times 10^{8}$ \\
\hline Eubacterium & $10>$ & $10>$ & $10>$ & $10>$ \\
\hline Peptococcus & $10>$ & $10>$ & $10>$ & $10>$ \\
\hline Clostridium & $1.2 \times 10^{4}$ & $10>$ & $8 \times 10^{7}$ & $4 \times 10^{7}$ \\
\hline 嫌気性菌総数 & $8.4 \times 10^{7}$ & $1.4 \cdot 10^{8}$ & $1.4 \times 10^{9}$ & $4 \times 10^{8}$ \\
\hline
\end{tabular}

抗菌剤（一）群において固形飼料群と ED 群を比較 してみると，狭窄（一）群では E. coli，Klebsiella， bacteroides, Eubacterium, Clostridium において, ED 群に菌数の減少がみられ，ED 単独でも antibacterial colon preparation としての効果が認められた. しかし 狭窄 $(+)$ 群では, これら各菌種において, 固形飼料群 と ED 群との差は認められず， ED の antibacterial colon preparation としての効果は認められなかった.

Kanamycin は Strept. faecalisをのぞくすべての好気性 菌に対し優れた有効性が認められ，腸内常在好気性菌の 主要菌である E. coli をはじめ Klebsiella, Proteus に おいて, 抗菌剤 (一) 群に比べ, 著しい菌数の減少が認 められた. とくに狭窄 (一) 群では, これらの各菌種に 対する knamycin の抗菌力は ED 群においてさらに増 強され，EDの相乗効果が認められた. Metronidazole は腸内嫌気性菌の主要菌である Bacterides をはじめと するすべての嫌気性菌に優れた抗菌力を示し，狭窄の有 無にかかわらず，全菌種において，固形群・ED 群ほぼ 同程度の抗菌作用が認められた。以上から antibacterial preparation としては好気性嫌気性雨方の立場から，Kanamycin・Metronidakole の併用が，Strept. faecalis を 除いたすべての検索菌の減少をもたらし有効であると思 われた。

\section{III. 大腸癌症例における臨床的検討}

\section{1. 対象および方法}

antibacterial preparation としての ED と Kanamycin, Metronidazole の効果を検討するために，大腸手術

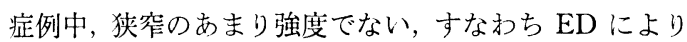
十分な mechanical preparation が期待できる症例につ いて, naso-duodenal に挿入した ED チューブより術前
4 日間エレンタールを投与し，抗菌剂として Kanamycin $3 \mathrm{~g} /$ 日， Metronidazole $750 \mathrm{mg} /$ 日を 3 日閒経口投与し た. E. coli, Klebsiella, Strept. faecalis, Bacteroides を指標菌として，細菌学的検討を行った．腸内が ED の mechanical preparation の効果によりほとんど空虚 になっているため, 有形の便に対する細菌学的検討は不 可能であり, 腸内容の採取は, 術中に腫瘍口側の結腸に $10 \mathrm{~cm}$ 間隔で腸鉗子をかけ，この部位の腸管内に嫌気性 菌に対する配慮から光岡 ${ }^{8)}$ の希釈液 $10 \mathrm{ml}$ を注入し，腸 内容の浮遊液を作り，その $1 \mathrm{ml}$ を採取し，これをラッ トにおける実験と同様の方法で培養し, 各菌の検出限界 を $10^{2}$ 個として菌数計算を行った.

2. 結 果

$\mathrm{ED}$ 単独群 $(\mathrm{n}=9)$ では E. coli は $10^{4} \sim 10^{9}$, Klebsiella $は 10^{4} \sim 10^{9}$, Strept. faecalis $は 10^{6} \sim 10^{9}$, Bacteroides は106 $10^{9}$ それぞれ検出された. これをコン トロール上して他群と比較すると, KM 群 $(\mathrm{n}=7)$ で は kanamycin の好気性菌に対する抗菌作用により $\mathrm{E}$. coli, Klebsiella はそれぞれ一検体に $1 \times 10^{4}, 2 \times 10^{4}$ 個検出されたのみであったが，全例に Strept. faecalis は107〜109, Bacteroides は $10^{6} \sim 10^{9}$ 個検出された. 次に MTN 群 $(\mathrm{n}=6)$ において, metronidakole は Bacteroides にすぐれた抗菌作用を示し, 全体で $10^{2}$ 以下であ ったが, 好気性菌に対する抗菌作用は認められなかった。 $\mathrm{KM}+\mathrm{MTN}$ 群 $(\mathrm{n}=5)$ では, E. coli, Bacteroides, はすべて $10^{2}$ 以下であった. しかし Strept. faecalisに 対しての抗菌性は認められなかった（表 4).

\section{VI. 考察}

大腸手術が他の消化器手術と異なる点として腸内容の 存在が上げられ, 術中の腸内容による腹腔内・腹壁創の 污染や, 吻合部にかかる内圧などは術後創感染・縫合不 全などの術後合併症につながる要因の一つとなってい る. 寸なわち大腸外科においては術前処置 (colon preparation)を mechanical, antibacterial の両面にわた り行うことが創感染・縫合不全などの術後合併症を減少 させ，手術成績を向上させるためにきわめて重要といえ る. mechanical preparation の方法としては従来から のものとして低残渣食の摂取, 各種下剂の投与, 浣腸の 施行がある。たしかに通過障害のない症例であれば，こ れらの処置により十分な腸内容の排除が可能であろう. しかし全周狭窄型大腸癌のように狭窄部口側腸管にすで に多量の便塊の貯留がある場合には宿便傾向が強く腸内 容の排除は不十分なことが多いだけでなく，浣腸に伴う 苦痛, 下剂の投与による腹痛の出現, 内圧の上昇による 腸穿孔の仜険性なども考慮しなければならない。 また最 
表 4 大晹幍症例の colon preparation 之腸肑生菌数

\begin{tabular}{|c|c|c|c|}
\hline & E. coli & Klebsiella & Strept. faecalis \\
\hline \multirow{9}{*}{ ED 単独群 } & $2.1 \times 10^{4}$ & $3.6 \times 10^{4}$ & $1.9 \times 10^{6}$ \\
\hline & $3.4 \times 10^{4}$ & $8.5 \times 10^{6}$ & $6.5 \times 10^{7}$ \\
\hline & $6.1 \times 10^{6}$ & $2.6 \times 10^{5}$ & $6.3 \times 10^{7}$ \\
\hline & $3.5 \times 10^{4}$ & $3.2 \times 10^{5}$ & $2.5 \times 10^{6}$ \\
\hline & $4.0 \times 10^{7}$ & $6.2 \times 10^{5}$ & $4.6 \times 10^{6}$ \\
\hline & $5.2 \times 10^{9}$ & $2.5 \times 10^{8}$ & $8.2 \times 10^{9}$ \\
\hline & $2.0 \times 10^{5}$ & $3.9 \times 10^{9}$ & $3.6 \times 10^{8}$ \\
\hline & $2.8 \times 10^{4}$ & $6.8 \times 10^{4}$ & $2.1 \times 10^{6}$ \\
\hline & $6.5 \times 10^{5}$ & $3.1 \times 10^{6}$ & $4.3 \times 10^{7}$ \\
\hline \multirow{6}{*}{$\mathrm{ED}+\mathrm{KM}$ 群 } & $<10^{2}$ & $<10^{2}$ & $3.2 \times 10^{4}$ \\
\hline & $<10^{2}$ & $<10^{2}$ & $6.0 \times 10^{6}$ \\
\hline & $1.0 \times 10^{4}$ & $<10^{2}$ & $3.6 \times 10^{7}$ \\
\hline & $<10^{2}$ & $2.0 \times 10^{4}$ & $2.5 \times 10^{8}$ \\
\hline & $<10^{2}$ & $<10^{2}$ & $4.0 \times 10^{6}$ \\
\hline & $<10^{2}$ & $<10^{2}$ & $3.6 \times 10^{9}$ \\
\hline \multirow{6}{*}{$\mathrm{ED}+\mathrm{MTN}$ 群 } & $2.5 \times 10^{6}$ & $3.5 \times 10^{5}$ & $5.8 \times 10^{6}$ \\
\hline & $5.3 \times 10^{5}$ & $4.8 \times 10^{9}$ & $2.6 \times 10^{7}$ \\
\hline & $5.7 \times 10^{8}$ & $3.2 \times 10^{8}$ & $4.0 \times 10^{6}$ \\
\hline & $2.9 \times 10^{5}$ & $5.4 \times 10^{6}$ & $5.6 \times 10^{8}$ \\
\hline & $4.1 \times 10^{4}$ & $2.5 \times 10^{5}$ & $1.2 \times 10^{6}$ \\
\hline & $2.5 \times 10^{7}$ & $6.9 \times 10^{8}$ & $2.0 \times 10^{7}$ \\
\hline \multirow{5}{*}{$\mathrm{ED}+\mathrm{KM}+\mathrm{MTN}$ 群 } & $2 \times 10^{4}$ & $<10^{2}$ & $2.4 \times 10^{6}$ \\
\hline & $<10^{2}$ & $<10^{2}$ & $4.5 \times 10^{7}$ \\
\hline & $<10^{2}$ & $<10^{2}$ & $3.6 \times 10^{8}$ \\
\hline & $<10^{2}$ & $<10^{2}$ & $4.9 \times 10^{7}$ \\
\hline & $<10^{2}$ & $<10^{2}$ & $5.6 \times 10^{7}$ \\
\hline
\end{tabular}

近では whole gut irrigation, ${ }^{90)}$ mechanical preparation として行っている施設もある隹，本法についても胃 ゾンデに伴う不快感, 腹痛, 腹満, 嘔気, 使用する洗浄 液による電解質の損失, 循環器系への負担などの問題が ある. ED は元来 Greenstein ${ }^{11}$, Winitz ら ${ }^{12)} に よ り$ 経 腸的な高力ロリー補給の目的で開発されたものであり, そのほとんどすべてが，上部小腸で吸収され残渣を残さ ないといら特性13)から, 大腸外科における colon preparation に使用されている.炭山ら 3 によれば EDによる colon preparation の成功率は $95.8 \%$ で, 従来の下剂, 浣腸に見られる苦痛はほとんどなく, 各種栄養指標の変 動, 術後創感染. 縫合不全からみた臨床的検討からも, きわめて有効であった．とくに大腸癌による通過障害を 想定した狭窄モデルラットの実験から, 狭窄があって

も, ED の特性が効果を示し, 十分な mechanical preparation が期待できることが証明された. Winitz ら ${ }^{14)}$ は ED はさらに antibacterial preparation としての効 果があると報告しているが, Bounous ${ }^{15)}$, Gurry ${ }^{16)}$ ，川村 ら 17) は ED 単独ではこの効果は認められないとしてい る. 今回のラットの実験結果から、狭窄 (一) 群におい
ては ED 単独群において E. coli, Klebsiella, Bacteroides の減少が見られ, antibacterial preparation 上して の効果が認められたが, 狭窄（十）群に拀いてはまった くその効果は認められず, antibacterial preparation 上 しては抗菌剂投与の必要性を認めた。 antibacterial preparation としての抗菌剤の投与については Garlock ${ }^{13)}$, Washington ${ }^{19)}$, Nicholas ${ }^{20)}$, 小野ら ${ }^{7)}$ の報告があり, mechanical preparation とともに大腸術前処置として久 くことのできないものである. 使用する抗菌剤について は，多くの報告があるが，好気性菌嫌気性菌雨面を考慮 し, Kanamycin と Metronidazole の併用を有効すると する報告が多い，われわれも Knamycin, Metronidazole を用い，狭窄モデルラットにおける詳細な検討から，両 者の併用投与が最も有効であることを確認したが, 他の 報告と異なる点として, mechanical preparation として ED を使用している点であり, antibacterial preparation においても，EDの使用により抗菌作用の相乗効果が認 められたことは注目に值する.大腸癌手術症例における 臨床的検討からも, ED と Kanamycin, Metronidazole の併用による術前処置が有効であった。

\section{V. まとめ}

ED による colon preparation の効果を抗菌剤との 併用による腸内細菌叢の変動から検討した.

1) $\mathrm{ED}$ 単独の antibacterial preparation としての 効果は狭窄（一）ラットに扔いては認められたが，狭窄 （十）ラットに㧍いては無効であり，抗菌剤投与が必要 と思われた。

2）好気性菌嫌気性菌两方に対寸る抗菌作用から antibacterial preparation としては Kanamycin と Metronidazole の併用投与が有効であることが実験的, 臨 床的検討から確認された。

3) 狭窄 (十) ラットの検討では, 固形飼料群では併 用抗菌剤の効果は減弱したが, $\mathrm{ED}$ 群では狭窄 (一) 群 と同样の抗菌作用が認められた. 以上から, 宿便傾向に ある大腸癌手術症例に対しては mechanical の面だけで

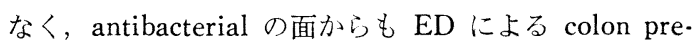
parationは必須のものであると思わ机た。

本稿の要旨は，第39回日本大腸胑阴病学会総会掞よび 第 4 回経腸栄養研究会にて発表した.

\section{文献}

1）炭山嘉伸, 長尾二郎, 鶴見清嵃: 今日の臨床外 科栄犎, 病態別栄络管理一大腸。外科診療 25 : $1237-1244,1983$ 
2）炭山嘉伸，長尾二郎，横山隆捷：全䧓狭穿型大 腸モデルに対する Elemental diet の colon preparation. 日本大腸肛門病会誌 $18: 22-27$, 1983

3）檪山嘉伸, 長尾二郎, 鈴木秀明：全周狭窄大腸 癌に対する colon preparation と術前術後栄養 管理。日臨外医会誌 $44: 616-619,1984$

4）横山隆津：成分栄養法による大腸術前処置に関 寸る研究一とくに抗菌剂の併用による antibacterial prpeparation に関する実験一。 日消外 会誌 $19: 948-956,1986$

5) 加藤文㢇, 岩井昭彦, 細野 進：下部消化管術 後感染の予防上対策。外科治潦 $49: 20-24$, 1983

6) 平山隆, 正宗良知, 斉藤俊博：大腸手術にお ける術後感染とその子防対策— polymyxinB, tinidazole 併用投与の効果について一. 日消外 会誌 $15: 826-830,1982$

7）小野成夫，小平進，滝沢建：大腸手術の術 前腸管処置の検討- metronidazole, kana mycin 併用投与の有効性について一. 日消外会誌 $14: 86-90,1982$

8) 光岡知足: 腸内細菌暴の検索手技. 感染症会誌 $45: 406-419,1971$

9) Raphael SC, Nelson JG, Berglund EM : A controlled clinical trial of whole gut lavage as a method of bowel preparation for colonic operations. Am J Surg 137 : 75-80, 1979

10) Hares MM, Williams JA: The effect of bowel preparation on colonic surgerey. WorId J Surg 6 : 175-181, 1982

11) Greenstein JP, Otey MC, Bimboaum SM : Quantitative nutritional studies with watersolble chemical defined diet. Arch Biochem Biophys 72 : 396-401, 1957
12) Winitz M, Seedman GA, Graff J : Studies in metabolic nutrition employing chemically defined diet: I. extended feeding of normal human adult males. Am J Clin Nutr 23 : $525-545,1970$

13）長尾二郎：大腸手術前管理, 佐藤博監修, 小越 章平編．経腸栄養．東京，朝倉書店，1984，p . p. $270-279$

14) Winitz $M$, Adams RF, Seedman DA : Studies in metabolic nutrition employing chemically defined diet: II. effects on gut microflora popuration. Am J Clin Nutr 23 : 546-559, 1970

15) Bounou G, Derroede CJ: Effects of an elemental diet human fecal flora. Gastroenterology $66: 210-214,1974$

16) Gurry J F, Ellis-Pegler R B : An elemental diet as preparative preparation on the colon. Br J Surg 63 : 969-972, 1976

17）川村 功, 小越章平, 確井貞仁 : Elemental dietによる経腸的 Hyperalimentaion (11) 大腸 外科における有用性について。外科 $42: 634$ 637,1980

18) Garlock JH, Seley GP: The use of sulfanilamide in surgery of the colon and rectum : Preliminary report. Surgery 5:787794, 1939

19) Washington JA, Derring WH, Judd ES : effect of preparation antibiotic regimen on development of infection after intestinal surgery. Ann Surg $180: 567-572,1974$

20) Nicholas R L, Broido P, Condon R E : Effect of preparation neomydin-erthromycin intestial preparation on the incidence of infectious complication following colon surgery. Ann Surg 178 : 456-462, 1973

(昭和63年: 7 月 8 日受付) 


\title{
Experimental and Clinical Reviews on the Variation of Micro Flora in the Colon upon the Colon Preparation with Elemental Diet
}

\author{
Y. Sumiyama, J. Nagao and S. Nakamura \\ Third Department of Surgery, Toho University
}

The colonic contents are to be considered for the factors of incomplete suturing or the infection at the damaged site as a complication after the surgery of colonic and rectal cancer.

We reviewed the importance of colon preparation for the variation of micro flora in the colon experimentally and clinically.

Rats of Wistar strain were used for the experimental review. After the parenteral nutritional method (ED) was performed, the antibiotics such as Kanamycin (KM), Metronidazole (MTN), and KM+MTN were orally administered for 4 days each. Then, we reviewed the variations of aerobic bacteria and unaerobic bacteria upon the colonic contents compared with ED single group. Moreover, we similarly reviewed by forming stenosis at the colon of each rate.

In the clinical review, we bacteriologically reviewed $\mathrm{ED}$ single group, $\mathrm{ED}+\mathrm{KM}$ group, $\mathrm{ED}+\mathrm{MTN}$ group and $\mathrm{ED}+\mathrm{KM}+\mathrm{MTN}$ group for the colonic and rectal cancer cases with not so severe stenosis, in other words, the cases to be able to perform enough mechanical preparations. 